notwithstanding that they are not the subject of a caveat by the original grantee of the interest (Hughes). The principle that such rights and priorities can derive from the fortuitous mention of Hughes in the lessee's caveat is one that could severely shake the structure of our Torrens system.

One must certainly sympathize with Hughes' position, at least against Gidosh, for the latter knew at all times what the former's claims were. However, the smooth operation of the Land Titles system must sometimes prevail in the face of individual hardship, ${ }^{24}$ and such operation will be greatly impaired if the Hughes v. Gidosh case stands. Nonetheless, for the moment the case should have some effect on the practices followed in conveyancing in this jurisdiction.

-E. MIRTH*

\footnotetext{
44 This is evidently intended by the legislators who enacted Section 203 of the Act. Perhaps there is enough of a case to support a finding of fraud within the intent of the Land Titles Act: sec cases discussed in Thom's Canadian Turre'ns System, supru, n. 11 at 219.

- B.A., LL.B., (Alberta), member of the Alberta Bar.
}

\title{
SOME RANDOM REFLECTIONS ON THE NO-FAULT CONCEPT
}

Mr. J. H. Laycraft's scholarly article on Reforming the Automobile Tort System ${ }^{1}$ seems to have done nothing for Geoffrey W. R. Palmer, B.A., LL.B. (Victoria University of Wellington), J.D. (Chicago), Assistant Professor of Law, University of Iowa, Iowa City, Iowa, U.S.A., except to arouse his ire, judging by the piece he wrote in response, ${ }^{2}$ wherein he deals with Mr. Laycraft, as well as the latter's views and advocates the very radical proposal made by a New Zealand Royal Commission in 1967. In addition to accusing Mr. Laycraft of making a "timid response to the demands for change" and being "somewhat misleading on the subject of delay in the common law," the irate Professor refers to the recent Report of the Legislative Committee on Automobile Insurance presented to the Legislative Assembly of Alberta, which made recommendations similar to those advanced by Mr. Laycraft, as "uninformative, uninspired, unconvincing and poorly researched." Presumably, in the Palmer philosophy, only those who espouse radical causes possess courage, and the documents of the democratic process, even in sunny Alberta, should conform to academic standards.

The Assistant Professor chides Laycraft, the advocate, for not mentioning some of the pertinent published literature. The fact is the volume of that literature has reached such formidable proportions that few practitioners could find the time to peruse and digest it all. Apart from referring to the Laycraft article, the Professor does not seem to have cited any literature adverse to his own point of view, unless it be buried in some footnote.

It would be difficult to go further afield for a precedent than New Zealand whose Royal Commission is said to have made a trip to

1 (1970) 9 Alta. Law Rev. 22.

2 Abolishing the Personal Injury Tort System: The New Zealand Experience, (1971) 2 Alta. Law Rev. 169. 
Canada and been so impressed with the administration of the Workmen's Compensation Acts, particularly in Ontario, that it decided similar bodies should assess all personal injuries to which mortal flesh is accidently susceptible. ${ }^{3}$

While there is a perennial need for continuing and orderly reform of the law and its administration, revolutionary proposals rarely produce revolution and often produce nothing but sound and fury. Is there any more hackneyed, uninspired or sterile doctrine than that of collectivism and associated theories with their ingenuous and abounding faith in bureaucracies? On this subject, of course, the adversaries make as much progress in composing their differences as do the Knights of Columbus and the Orangemen in Ireland or the Israelis and the Arabs in the Middle East; hence, the socialists will continue to ignore such orthodox questions as (i) could Alberta afford the revolutionary New Zealand proposal? (ii) how would we liquidate the automobile and liability insurance business, their employees and agents, plus the members of the bar who practice in this field? and (iii) is our generation incapable of developing any new solutions to social problems, and must the answer forever be to turn the whole baffling business over to officialdom or its alter ego the Crown corporation, and let the Devil take the "timid" souls who worry about justice, taxes and inflation?

One marvels at the apparent ruthlessness of some implications of such proposals for alleged "reform", particularly regarding their effect upon those who do not subscribe to the ideologies of the "reformers". The radical, socialistic New Zealand proposal would put a number of insurance companies, their employees, agents and adjusters out of business and would deprive the legal profession of a substantial volume of practice. No one in his right mind would suggest that these considerations constitute any reason whatsoever against progress or genuine reform, but the persons affected are decent, law-abiding, taxpaying citizens and should be entitled to some better fate than total disappearance under the massive march of "social" progress. For their sake as well as the public's let us be certain that new and untried schemes are sound before we implement them.

As usual, there is disagreement as to the relevant facts and apparently no machinery to resolve the issues. ${ }^{4}$ The Professor seems to assume that the situation is substantially the same wherever there is a common law heritage. Mr. Laycraft speaks from personal knowledge of the facts in Alberta but by skilful innuendo his erudite opponent disqualifies him, the whole organized bar and the insurance people on the ground of their obvious self-interest. Thus, at one bold, dialectic stroke, all of those who are best informed are disqualified, leaving the "liberal" intelligentsia in sole possession of the rostrum. Where do they get their information? Presumably, by sampling

\footnotetext{
1 With the media reporting very much larger awards in other jurisdictions, it might require a small army of ombudsmen to deal with the complaints of those who would have had their claims for personal injuries processed promptly by a provincially-appointed board, without apparent expense or benefit of counsel.

- Adverse arguments based upon materially different facts result in a dialogue at cross purposes, and leave room for the suspicion that some of the findings of fact were made before the evidence was examined. Perhaps, one of the human foibles of the dedicated social reformer is a tendancy to overlook data that conflict with his preconceived assumptions.
} 
techniques, casual investigations or reading the literary works of their own partisans.

The highly respected and influential American Bar Association has pronounced itself in favour of the adversary system, but has been unable entirely to stem the no-fault movement in the United States. According to the American Bar Association Journal,5 Massachusetts has adopted the no-fault concept, the Senate Subcommittee on Antitrust and Monopoly made a three-year study of the problem, its Chairman has introduced legislation at the last two sessions of Congress that would federalize the automobile insurance system on a no-fault basis, and, the Nixon administration seems committed to the concept. Of course, all of this is a far cry from the radical New Zealand proposal to abolish the entire common law system for compensating personal injury losses.

In Alberta, current indications are that public opinion will continue to view social problems realistically and to favour evolution rather than revolution. Costly experiments in other jurisdictions will be observed and the results assessed. For the present, the amending legislation that resulted from the Report of the Legislative Committee on Automobile Insurance and improved practices by enlightened insurers constitute the type of orderly evolution that is consistent with the character and temper of the people of Alberta.

-J. J. SAUCIER, Q.C.*

; (1971) 57 Am. Bar. Assoc. J. 487.

- B.A., LL.B., (Alberta); D.C.L. (Dallas); Past President, The Law Society of Alberta and The Canadian Bar Association.

\section{SOME RECENT DEVELOPMENTS IN THE LAW OF MATRIMONIAL PROPERTY}

Two recent House of Lords decisions have drastically changed the approach to be used by the English courts in matrimonial disputes. ${ }^{1}$ These decisions have now been applied by the Alberta Appellate Division in the case of Trueman v. Trueman ${ }^{2}$ which resulted in a farm wife receiving a beneficial half interest in the family farm as a result of her substantial, though non-financial, contributions to the acquisition of the property. In this comment, an attempt will first be made to understand the full implications of the Trueman decision, an undertaking which will necessitate an examination of the House of Lords decisions in Pettitt v. Pettitt ${ }^{3}$ and Gissing v. Gissing. ${ }^{4}$ The second part of the comment will be an attempt to reconcile the Trueman decision with Thompson v. Thompson, 5 a 1960 Supreme Court of Canada decision, which has been interpreted widely as having put

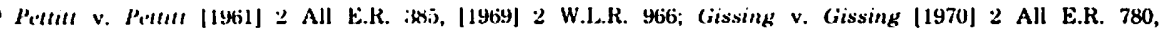
[1970] 3 W.L.R. 2:5i.

[ [1971]2 W.W.K. 6s8, (1971) Is |).L.K. (3d.) I09.

Supra, n. 1.

' ld.

[1961] S.C.R. 3, (1960) 26 D.L.R. 1. 